\title{
The Stakes in Bayh-Dole: Public Values Beyond the Pace of Innovation
}

\author{
Walter D. Valdivia
}

Published online: 20 February 2011

(C) The Author(s) 2011. This article is published with open access at Springerlink.com

\begin{abstract}
Evaluation studies of the Bayh-Dole Act are generally concerned with the pace of innovation or the transgressions to the independence of research. While these concerns are important, I propose here to expand the range of public values considered in assessing Bayh-Dole and formulating future reforms. To this end, I first examine the changes in the terms of the Bayh-Dole debate and the drift in its design. Neoliberal ideas have had a definitive influence on U.S. innovation policy for the last thirty years, including legislation to strengthen patent protection. Moreover, the neoliberal policy agenda is articulated and justified in the interest of "competitiveness." Rhetorically, this agenda equates competitiveness with economic growth and this with the public interest. Against that backdrop, I use Public Value Failure criteria to show that values such as political equality, transparency, and fairness in the distribution of the benefits of innovation, are worth considering to counter the "policy drift" of Bayh-Dole.
\end{abstract}

Keywords Bayh-Dole - Evaluation - Public values · Pace of innovation · Political equality

\section{Introduction}

In the last three years, Congress has intensified scrutiny of the Bayh-Dole Act (P.L. 96-517)— - holding hearings to assess the first 25 years of this policy (U.S. House of

\footnotetext{
W. D. Valdivia $(\bowtie)$

Consortium for Science Policy and Outcomes, Arizona State University,

PO Box 875603, Tempe, AZ 85287-5603, USA

e-mail: walter.valdivia@asu.edu

W. D. Valdivia

Department of Environmental Science, Policy, and Management,

University of California Berkeley, Berkeley, CA 94720-3114, USA
} 
Rep., July 17, 2007), to revise a rarely used provision ${ }^{1}$ (U.S. Senate, October 24 , 2007), and more recently, to consider the possibilities for improving the technology transfer regime (U.S. House of Rep., June 10, 2010). In the most recent hearing, Rep. Daniel Lipinski (Dem.-IL), chair of the Technology and Innovation Subcommittee, announced that the intention of the subcommittee is "to carry out a comprehensive review of the Bayh-Dole and Stevenson-Wydler Technology Innovation Acts later this year." Anticipating that Congress may eventually muster the political will to amend Bayh-Dole, the National Research Council (NRC) commissioned a consensus report on university management of intellectual property that was recently published (NRC 2010). Because that report synthesizes the voluminous literature that assesses Bayh-Dole, this paper could be read as a companion study that points out lacunae in the literature.

The vast majority of evaluation studies of the Bayh-Dole Act (the "Act") are either concerned with its effects on the pace of innovation or concerned with the culture and organization of academic research. Studies of the first type examine, for example, the possible loss of quality in university research (e.g. Henderson, Jaffe, and Trajtenberg 1998; Jensen and Thursby 2001; Mowery et al. 2004; Mowery and Ziedonis 2002; Rafferty 2008; Sampat, Mowery and Ziedonis 2003), the threats to basic research from the "enclosure" of the scientific commons (Heller 1998; Heller and Eisenberg 1998; Shapiro 2000; cf. Walsh, Arora, and Cohen 2003), and the friction brought about by aggressive bargainers of intellectual property (Jaffe and Lerner 2004; Thursby and Thursby 2006). These are presented as problems because they risk slowing down innovation. Studies of the second type believe in an ideal set of norms for academic research, an "academic ethos" that encompasses norms such as the public dissemination of research, impartiality in peer-review, and faculty discretion over the curricula and the research agenda. These authors argue that since Bayh-Dole was enacted, the transgressions to these norms have become more frequent and pervasive (Greenberg 2007; Judson 2004; Slaughter and Leslie 1997; Slaughter and Rhoades 2004; Washburn 2005). While both concerns must to be taken into consideration to understand the Bayh-Dole regime, I argue in this paper that limiting our attention to them narrows the scope of analysis and misses other important values. For instance, "distributive equity" or "political equality" are much more adequate values for evaluating outcomes such as affordability of new medical treatments or processes such as bureaucratic regulation of patent-based monopolistic practices.

To redress this narrowness in conventional evaluations of Bayh-Dole, I take a different approach to evaluation. This approach, called Public Value Mapping (Bozeman 2002, 2007), allows me to explicitly consider public values other than the pace of innovation or transgressions to the academic ethos. In order to expand the scope of values considered, it is necessary to understand the public values that currently dominate the institutions and discourses of the Bayh-Dole regime. It is necessary as well to examine how the balance between those dominant values

\footnotetext{
1 This provision requires government-owned-contractor-operated facilities to pay the government a $75 \%$ of any portion of net operating licensing income (i.e. net of related expenses) that exceeds $5 \%$ of the facility's operating budget (35 U.S.C. \$202-C-7-E-i).
} 
shifted in time, transforming in turn the terms in which Bayh-Dole was debated and implemented. The examination of this dual drift problem - the simultaneous "drift" in the policy design and the policy debate-is integral to my analysis.

Before discussing the dual drift problem, I want to briefly describe what the Public Value Mapping (PVM) approach is and why it is suitable for the evaluation of Bayh-Dole. Considering that public values are latent in all facets of policy, from the formation of expectations to the evaluation of outcomes, PVM is an approach to examine policy through the lenses of the intervening public values. PVM redirects attention in policy analysis from cause-and-effect relations to the articulation-andrealization of public values in the making of policy. Why PVM is useful to examine Bayh-Dole? The answer follows from two premises. First, the predominant criteria of policy evaluation, the Market Failure Criteria (MFC), are also common rationales for policy: government is justified to intervene in the economy only to correct noise in the price mechanism. Second, Bayh-Dole is a canonical policy solution to a market failure problem. The alleged problem is that firms are reluctant to invest in product-development if they cannot appropriate the potential returns of their investment, in this case, by keeping exclusive rights to the patents of those products. The Bayh-Dole solution consists in creating a market for those patents: government transfers its patent rights to universities, and universities can lease those patents to firms. It follows from these premises that, evaluation studies that use the Market Failure Criteria will conclude that the Act has been an unqualified success because it did in fact create a market for public patents. If evaluators disagree, it will be only about the degree of success - as measured by the effectiveness of the appropriation mechanism, or how much development and commercialization were really streamlined, or whether the incentives introduced have perverse effects. However, market failure studies cannot assess the other half of Bayh-Dole on its own merits because they must apply the same evaluation standard to all provisions; under that light, the provisions to keep a check on the profit motive are bound to be considered unnecessary. PVM in turn is normatively more flexible than market failure. It starts by identifying the public values that motivated those provisions and then examines whether those values were realized in the evolution and implementation of BayhDole. The normative criteria of PVM are concerned with the realization of core public values in the policy-making process without necessarily privileging the operation of the markets. In Section Public Value Failure in the Bayh-Dole Regime, I probe Bayh-Dole with the Public Value Failure Criteria.

At this point I should make a conceptual digression to explain my use of "policy design." I use this term in the sense of Schneider and Ingram (1997) to refer to the "substance of public policy"; that is, the "blueprints, architecture, discourses, and aesthetics of policy" (p. 2). The use of policy design underlines my stance in policy analysis that conceives of policy as a fluid institution rather than a crystallized rule, and deals with policy-making as an ongoing political negotiation rather than a multi-stage linear process that commences in formulation and ends in implementation. As Schneider and Ingram (1997) point out, the letter of the law is fixed but only until the law is amended or modified by other statutes, and more pervasively, the letter of the law is always subject to different interpretations and those interpretations are subject to contestation. 
Returning to the dual drift problem, I argue that the systematic changes in both the Bayh-Dole debate and the policy design can be traced to the ascendancy of neoliberalism over U.S. policy-making and to the reforms to the patent system (including the amendments to the Bayh-Dole statute). I treat these factors as two analytical threads recognizing that they are entwined and interdependent.

The influence of neoliberal ideas over social and economic policy, over the last three decades and on both sides of the Atlantic, cannot be underestimated. Neoliberalism is hard to catalogue; it has been variously defined as a doctrine of political economy (Harvey 2007), an ideology (Turner 2008), and a "thought collective" (Mirowski 2009). For all its internal plurality, its adherents share a fundamental commitment to private property, free markets, and a strong state to enforce the law. The neoliberal defense of free markets acquires a political dimension when it equates freedom with free markets, adding a moral imperative to the classical justification of markets as the most efficient mechanism for the allocation of resources. Furthermore, the neoliberal state ought to be small but strong enough to effectively enforce the law, property rights, and secure the untroubled operation of markets. The dual prescription of unfettered markets and an assertive state have pervaded all policy domains, and in the case at hand, their decisive influence on the Bayh-Dole regime has been amply noted (Mirowski and Sent 2007; Nedeva and Boden 2006; Pestre 2005; Slaughter and Rhoades 2004). In Section The Changing Terms of the Bayh-Dole Debate, I bring these arguments to bear and discuss the centrality of "competitiveness," as a key public value and a rhetoric trope, to the terms of the Bayh-Dole debate.

The second factor driving the policy drift in Bayh-Dole can be decomposed into two components, "bureaucratic drift" (McCubbins et al. 1987) and "legislative drift" (Horn and Shepsle 1989). Bureaucratic drift-that is, changes to the policy by administrative discretion-resulted from the failure of the enacting coalition to establish administrative procedures that would effectively constrain the profit motive, particularly with respect to exclusive licenses and the emergence of "creative" licensing practices (e.g. reach-through clauses). Legislative drift-that is, subsequent statutory amendments to the law that alter its mechanisms and aims-was the consequence of not providing for institutional mechanisms to replicate the political pressures of the enacting coalition, particularly with respect to limited benefits for large firms and sufficient authority for federal agencies to safeguard the public interest. To understand why the enacting coalition arrived at a compromise with respect to checks on the profit motive, limitations on large firms, and administrative regulatory discretion, I review in Section Changes in the Design of Bayh-Dole the terms of the compromise achieved by the enacting coalition and account for the drift in terms of amendments to Bayh-Dole, and other changes in the patent law and the patent system, including the creation of the Court of Appeals of the Federal Circuit and key Supreme Court rulings on patentable subject matter.

The next two sections will engage respectively with the drift in the debate and the drift in the design setting the stage for the analysis of public value failure in the subsequent section. The last section draws some conclusions from this analysis. 


\section{The Changing Terms of the Bayh-Dole Debate}

The impetus for legislative reform does not come as a surprise when one considers that the Bayh-Dole debate has carried on for three decades and that critics of the Act have redoubled efforts to reform it, lately opening a new front of attack. Whereas past critics of the Act worried that the incentives to accelerate the commercialization of public research had a perverse effect on the performance of research itself (Heller and Eisenberg 1998; Heller 1998; Henderson, Jaffe, and Trajtenberg 1998; Merges and Nelson 1990; Mowery et al. 2004; Shapiro 2000), a new generation of critics now worries that Bayh-Dole does not facilitate research commercialization sufficiently well (Litan, Mitchell, and Reedy 2007; Kenney and Patton 2009). This latter group, led by researchers of the Ewing Marion Kauffman Foundation-a steward of entrepreneurship_-proposed to amend Bayh-Dole so that inventors retain title to their inventions and be given full discretion over those titles, instead of assigning those rights to their employers, the universities. They claim that the university is a bottleneck in the commercialization of research and that in order to avert a slowing down of innovation, scientists should be free to choose a partner to negotiate the development of their research (Litan, Mitchell, and Reedy 2007). In response, former senator Birch Bayh-one of the Act's sponsors and its staunchest defender-rebuked the Kauffman Foundation proposal, arguing that the university was an essential partner in the commercialization of public-funded research, and stressed that it was widely believed that Bayh-Dole promoted research commercialization and injected dynamism in the U.S. innovation system (Bayh, Allen, and Bremer 2009). Still, the Kauffman Foundation proposal was welcomed in the business community and endorsed by the influential Harvard Business Review (2010), and what is more, Lesa Mitchell, one of its authors and a vice-president at that foundation, was invited as a witness to the most recent Congressional hearing on Bayh-Dole.

If we remember that the 96th Congress would not have even considered BayhDole in 1980 had the proposed bill not included the university in the equation (see Stevens 2004; Washburn 2005, pp. 63-69), we cannot help to wonder: How did we get here? How can a proposal to exclude the university from technology transfer be given serious consideration? The answer lies in the changing terms of the BayhDole debate, particularly the importance that government officials ascribe to patent protection and an increasingly liberal attitude of university administrators towards patenting and licensing. Regarding patent protection, with few exceptions (particularly chemical and pharmaceutical industries) firms have not used patents as the primary strategy to secure the returns of their R\&D investments (Levin et al. 1987; Cohen et al. 2000, 2002). Still, during the last thirty years, all three powers of the U.S. government have strengthened patent protection (Scherer 2009) and even coerced U.S. trade partners to enforce IP law (Haskins 1998). It may seem that these changes to patent policy were driven more by a doctrinaire view of patents than the actual needs of industry.

Regarding the university in the Bayh-Dole regime, the change is visible in the attitudes of university administrators towards generating revenue from licensing intellectual property. While university patenting was increasing before 1980, the 
prevailing attitude at that time was that patenting was justified only in the public interest, and the public interest was thought best served by promoting wide diffusion of inventions through affordable non-exclusive licenses - this was precisely the case of the famous Cohen-Boyer patents. Today, university administrators are much more interested in supporting regional (or national) economic growth than in promoting the diffusion of inventions. Because they understand that growth is driven by industrial innovation and entrepreneurship, they feel the public interest is best served when universities contribute to the creation of new companies. They also know that the ultimate measure of entrepreneurial success is the firm's market capitalization (its market value in financial markets). In the case of high-tech startups, market capitalization depends on intangible assets, and more specifically, on whether the firm has exclusive rights to key patents. For this reason, university offices of technology transfer have fewer qualms about licensing on exclusive basis than they did thirty years ago; the public interest still guides their actions, only now the public interest is conflated with the university's financial need and the financial value of the firms taking licenses. Again, this change in the way university administrators construe the public interest seems guided by a doctrinaire view that privileges economic growth over diffusion of innovation-which is a form of economic distribution. Let me stress that these attitudinal changes are not arbitrary; rather, they seem to systematically favor property rights and profit maximizing behavior. This doctrinaire character of the changes is part and parcel of a larger political project called "neoliberalism." To understand the drift in the Bayh-Dole debate, it is thus necessary to account for the influence of neoliberal ideas on innovation and the patent system.

Let me start by giving some context to the emergence of neoliberal ideas in the U.S. By the time Bayh-Dole was enacted, in 1980, the thin political consensus on the welfare state was wearing thinner in the U.S. The electoral contest of that year brought a direct attack on big government and the institutions that represented, particularly in economic and social policy, the growth of governmental power. The economic debacle of the 1970s was the perfect excuse to declare the failure of any and all government intervention in the economy, including regulatory and redistributive policies. The discourse went beyond simply an electoral platform for it drew from the neoliberal project, a philosophical and political project that by that time had been in the making for nearly four decades. Neoliberalism has been given content by various schools on both sides of the Atlantic and across various disciplines-notably in economics, political philosophy, and law-and it is perhaps best understood as a thought collective rather than single coherent ideology (Mirowski 2009; cf. Harvey 2007; Turner 2008). The greatest affinity among its adherents is their shared desire to propose a practical alternative to the dominant Western traditions of social order: "laissez-faire classical liberalism, social welfare liberalism, and socialism" (Mirowski 2009, p. 431). The variety of intellectual programs and significant personalities (and egos) that conformed the neoliberal thought collective never allowed to enunciate a manifesto or even a statement of founding principles; however, most members share a fundamental belief in unfettered markets, private property, and a minimal but strong state; strong because it must be able to adjudicate property disputes between powerful interests (Plehwe 
and Walber 2006; Turner 2008). What is more, neoliberals refute the notion that monopolies are antithetical to free markets on the grounds that the prospect of monopolistic profits creates the incentive for firms to invest in R\&D; monopolies are thus necessary for innovation.

Although the word neoliberalism is not of common use in the U.S., ${ }^{2}$ the most important economic, trade, and regulatory policies introduced by every Administration since Reagan are canonical examples of neoliberal policy-making (Meeropol 1998; Pollin 2003; Van Horn and Mirowski 2009), for instance, deregulation (and later re-regulation), devolution, the 1995 welfare reform, and NAFTA. In the specific case of innovation policy, Slaughter and Rhoades (1996) observed the formation of a political coalition that successfully advanced a neoliberal agenda under the banner of promoting "competitiveness." The previous political force of innovation policy, the Cold War coalition, underlined the transformative character of basic research as the source of U.S. leadership over the Soviet Union. They believed that the autonomy of science was a necessary condition to unleash the creative forces of basic research and gradually expanded funding for the scientific establishment. The new coalition was formed in response to the emergence of Japan as an economic power and the seeming loss of competitiveness of the U.S. economy. They attributed the economic success of Japan to strong research in engineering and applied programs as well as the adoption of more efficient models of production and commercialization. Consequently, they sought to redirect government resources to support industrial R\&D and business interests. Slaughter and Rhoades (1996) are careful not to draw easy distinctions between these coalitions as they recognize that the emergence of the competitiveness coalition did not fully displace the Cold War coalition. However, these authors stress the increasing power of the new coalition in enacting key legislation such as the Bayh-Dole Act itself and its later amendments (see Section Changes in the Design of Bayh-Dole), the creation of the Court of Appeals of the Federal Circuit (P.L. 98-462), the subsidies to private sector R\&D through the Small Business Innovation Development Act (P.L. 97-219), the tax-credits for clinical trials of the Orphan Drug Act (P.L. 97-414), and dispensations on anti-trust law, including a seven year market exclusivity for developers of "orphan drugs" and an exempt status for R\&D joint ventures under the National Cooperative Research Act (P.L. 98-462). Admittedly, a policy agenda for stronger patent protection, subsidies and tax-credits for industrial $\mathrm{R} \& \mathrm{D}$, and softer anti-trust legislation, looks distinctly neoliberal. ${ }^{3}$

The encroachment of neoliberal values in the organization of innovation extended beyond the competitiveness coalition; in fact, it reached the very regime of knowledge production including researchers themselves (Nedeva and Boden 2006; Pestre 2003, 2005). The transition to the new mode of knowledge production, or

\footnotetext{
${ }^{2}$ Neoliberalism, in U.S. political parlance, is more closely aligned with conservatism than it is to liberalism. This is due to the curious reversal of meanings that dates back to President Roosevelt campaigning for the New Deal reforms and describing them as truly liberal reforms. He did this with such success that his political opponents eventually surrendered the word and adopted the label conservative for themselves (see Lowi 1995, p. 87).

3 Compare with Bruno (2009) who discusses "competitiveness" in the context of the European governance of innovation.
} 
"Mode 2," is characterized by greater attention to the context of application (Gibbons et al. 1994; Nowotny, Scott, and Gibbons 2001). This is not the application of theoretical or experimental knowledge typical of Mode 1, but the context of application "describes the total environment in which scientific problems arise, methodologies are developed, outcomes are disseminated, and uses are defined" (Nowotny et al. 2003, p. 186). In a Mode 2 research environment the researcher has professional incentives to produce use-inspired research, and these will be reinforced by the financial incentives attached to those "useful" research findings. To the extend that Mode 2 has not replaced Mode 1, the Bayh-Dole regime is a catalyst of the transition to Mode 2. Consequently, it could be expected a "normalization" of the research culture stylized by the Mode 2 description, including a legitimation of profit-seeking behavior in university patenting.

The drift in the Bayh-Dole debate is thus only a reflection of neoliberal ideas taking hold of policy-making in the U.S. At the legislative level, the competitiveness coalition reformed R\&D and patent law. At the university administration level it became more acceptable to engage in patenting and maximizing licensing income. Even at the level of academic research, the uptake of the market values of the BayhDole regime was reinforced by the emergence of fields like information technologies and molecular biology. The changing values at all these levels required a new lexicon to be communicated, and as Slaughter and Rhoades (1996) suggest, the primary rhetorical trope has been "competitiveness." For this reason, I now turn my attention to this term.

Competitiveness entered elite discourse with force about the same time BayhDole was passed. ${ }^{4}$ The three foremost voices of elite discourse-political leaders, journalists, and scholars-quickly took up the term. Politicians adopted competitiveness because it transcends party-ideology given that the term fits well with what McCloskey and Zaller (1984) call "the American ethos": the bipartisan agreement on public values such as personal freedom, self-help, and merit-based organization. In turn, mass communication media is in constant search for words that convey meaning, at once, intuitively and forcefully. Using LexisNexis Academic to track wires of the Associate Press and the print edition of the New York Times, I found that the term was used in the postwar period until 1980 a total of 117 and 201 times respectively; the use exploded in the 1980 s to 3,442 and 2,373, stabilized in the 1990s with 3,432 and 2,817 , and is likely to remain at that level during the last decade, with the count at 3,401 and 1,448 on July 2009. No less important for the pervasiveness of competitiveness was the host of academic new ideas-in economic theory, public management, corporate culture, and industrial policy-where the term came to symbolize new paradigms. For instance, the efforts to conceptualize competitiveness in economics led to revisions in the theory of "comparative advantage" (for instance, Fagerberg 1988) "conditional convergence" (for a theoretical and empirical synthesis, see Baumol, Nelson, and Wolff 1994). In public administration, competitiveness was central to the emergence of the "new public

\footnotetext{
${ }^{4}$ I use elite discourse in its standard definition in political science. That is "stereotypes, frames of reference, and elite leadership cues that enable citizens to form conceptions of and, more importantly, opinions about events that are beyond their full personal understanding" (Zaller 1992, p. 14).
} 
management" school (Hood 1991; surveys in Pollit and Bouckaert 2004, and Hood and Peters 2004). Corporate culture and industrial policy were influenced by the notion of "competitive advantage" pioneered by Porter (1980, 1990).

More than any specific meaning or definition, the pervasiveness of the term in elite discourse impressed on the public imagination the notion that competitiveness is a public value of consensus, similar in its unqualified virtue to justice or freedom. At that point, a whole array of social problems could begin to be articulated in terms of their deleterious effects on competitiveness: A deficient educational system creates less competitive workers; poor public health reduces the productivity of the labor force; higher taxes and welfare benefits undermine the incentives for getting ahead in life; government intervention creates frictions in otherwise competitive markets. Competitiveness became, in the words of Paul Krugman (1994), an obsession that bore the serious risk of lowering the quality of policy discussion: "If top government officials are committed to a particular economic doctrine, inevitably that sets the tone for policy-making on all issues, even those which may seem to have nothing to do with that doctrine" (p. 42).

Competitiveness became an all-purpose goal (if not an obsession) in policy discussions and it was elevated to be a public value of consensus in the public imagination. Unsurprisingly, Bayh-Dole and its subsequent amendments have been justified in terms of promoting competitiveness; Senator Bayh himself offered this reasoning during the hearings in 1980:

One of the greatest threats to our economic (and ultimately political) wellbeing is the recent slump in American innovation and productivity... American industry is simply not keeping up with its international competition in too many fields. While Government patent policy is by no means the only cause of this problem, it is certainly a contributing factor (U.S. Senate 1980).

The popularity of competitiveness, however, does not logically link patent policy and this value. There was indeed a more formal explanation that linked patent rights to competitiveness. First, economists define competitiveness in terms of national productivity-measured usually as national product per hour of labor. More precisely, competitiveness is the relative position of an economy in terms of productivity (Hatsopoulos, Krugman, and Summers 1988; see also Klein 1988). Second, economic theory since the 1960s has re-invigorated the old notion that innovation is the driver of long-term productivity gains, and consequently, of sustained economic growth. While the fluctuations of the business cycle are explained by the fluctuations in employment of the factors of production, in the long run, the size of the economy is capped by its productive capacity at full employment. Hence, only technological innovation can expand the frontier of production possibilities by making labor, capital, and land increasingly more productive. Third, the other old notion that patents introduce an incentive for innovation is also alive and well — although it had suffered some setbacks from the Progressive Era through the 1960s as policy-makers and the courts had favored, in some instances, anti-trust arguments over industrial patent rights. Fourth, and in relation to the previous point, it was believed that patent rights to public research (i.e. federally-funded research) were not clearly assigned because, unless prior 
agreement existed between research contractor and federal agencies, the government retained rights to those patents. I will elaborate on the latter point further in the next section, but here it is sufficient to stress that it was thought necessary to clearly assign patent rights to public research for the private sector to invest in the development and commercialization of that research. This linear causal relationfrom public support of research, to assignation of patents for private exploitation, to innovation, to productivity gains, to national competitiveness-linked Bayh-Dole to competitiveness and made of it a national cause.

I have argued thus far that the ascendancy of neoliberal ideas over policy-making and particularly over the innovation system were the primary source of drift in the Bayh-Dole debate, and that competitiveness is a good point of reference to identify neoliberal justifications of the Act and posterior reforms to its design. It is to that aspect that I now turn my attention, the drift in the design of Bayh-Dole.

\section{Changes in the Design of Bayh-Dole}

Bayh-Dole is today a very different policy than it was when enacted. To understand the drift in its design it is appropriate to revisit the political compromise that was inscribed in the first text of the Act and the subsequent amendments to it. The issue at stake in Bayh-Dole - the right to ownership of patents originated from government-funded research-dates back to the postwar debate on the institutional structure of U.S. science policy. Two prominent figures in that debate, Vannevar Bush, former director of the wartime Office of Scientific R\&D, and Senator Harley Kilgore, are representative of the opposing views on the issue of patents. Bush recognized the inventors' rights to their inventions; Kilgore, in turn, contended that the public interest was best served when the government retained ownership (Guston 2000; Sampat 2006).

For little more than three decades, the issue of a government-wide policy was revisited only twice. First, President Kennedy's memorandum of 1963 (36 F.R. 16889) explicitly asserted the government rights to public-funded inventions but granted certain latitude to federal agencies to transfer title to contractors or license government patents on exclusive basis under special circumstances and on reasonable terms. Then, President Nixon's memorandum and policy statement of 1971 (28 F.R. 90343) reaffirmed the administrative discretion granted by his predecessor but denied that a "single presumption of ownership of patent rights to Government-sponsored inventions" was a "satisfactory basis" for government-wide patent policy. ${ }^{5}$ What these memoranda reflect is a détente between parties in the Bush-Kilgore discord. Still, the conventional moral wisdom that public-funded research should lead to patents held in the public domain prevailed, not without permitting extraordinary and reasonable exceptions. This ambivalence of principle

\footnotetext{
5 See Woolley and Peters (2009b) for Presidential Memorandum of 1971 and see the Federal Register for the Policy Statement of August 26, 1971 (36 F.R. 16889) and the Policy Statement of October 11, 1963 (28 F.R. 90343).
} 
was reflected in administrative practice; federal agencies had as many as twenty-six different patent policies in force by the end of the 1970s (Eisenberg 1996, p. 1694).

Bayh-Dole ended the policy ambivalence and achieved uniformity in patent policy across most federal agencies ${ }^{6}$ but it did not end the Bush-Kilgore discord. By the late 1970s, many lawmakers-particularly those who fought the legislative battles for expanding the welfare state in the 1960s-would have scoffed at the idea of transferring government patent rights directly to industrial interests. The enacting coalition of Bayh-Dole had to overcome serious objections and in doing so it equipped it with provisions to balance the various intervening interests. ${ }^{7}$

The objections were mainly three. If the Act was enacted, it was feared that granting rights on profitable patents would be seen as a government giveaway to large industrial interests, that unrestricted exclusive licenses would promote noncompetitive practices such as excessive pricing and the stifling of potential competitors, and that taxpayers would be denied their fair share of returns on research investments that yielded profitable patents.

The balancing mechanisms were inscribed in the proposed bill (S. 414, introduced on February 9, 1979) and they were successful preempting the aforementioned objections. To neutralize accusations that this policy was a giveaway to corporations, the Act explicitly states its aim "to encourage maximum participation of small business firms in federally supported research" (35 U.S.C. $\S 200)$, requires that small businesses be given preference when granting a license (35 U.S.C. §202-c-7-D) and, when enacted in 1980, it limited the time length of exclusive licenses for large businesses to five years. To forestall allegations that the taxpayer's investments in research would never yield monetary return, the text of the Act-as originally introduced to the Senate-included a provision for the government to recoup a portion of the licensing income. Finally, and as the cornerstone of all safeguards against the lack-of-use, misuse, or abuse of titles or licenses, the Act established two mechanisms for government intervention before and after rights to title are granted. The first of these mechanisms allows funding agencies to limit or cancel the rights to an invention "in exceptional circumstances when it is determined by the agency that restriction or elimination of the right to retain title to any subject invention will better promote the policy and objectives of the Act" (35 U.S.C. §202-a-ii), namely, that inventions "are used in a manner to promote free competition and enterprise without unduly encumbering future research and discovery" (35 U.S.C. §200). The second provision has two elements. First, it requires contractors that take title to inventions to grant, in favor of the funding agency, a "nonexclusive, nontransferable, irrevocable, paid-up license" (35 U.S.C. \$202-c-4). Second, it confers the respective federal agency "march-in rights." These rights are legal authority for the agency to practice such a royaltyfree license under certain circumstances, primarily when "the contractor or assignee has not taken, or is not expected to take within a reasonable time, effective steps to

\footnotetext{
${ }^{6}$ Bayh-Dole exempts research programs directly tied to national security, especially at the Department of Defense.

7 See Stevens (2004) and Washburn (2005, Chap. 5) for accounts of the closed-door negotiations leading to the legislative agreement on Bayh-Dole.
} 
achieve practical application" and when "action is necessary to alleviate health or safety needs which are not reasonably satisfied by the contractor, assignee, or their licensees" (35 U.S.C. §203).

It would not be an exaggeration to say that, in 1980, not even the few skeptics of Bayh-Dole could imagine how weak and impractical were those safeguard provisions. The first blow to the safeguards was inflicted even before the bill was passed: the final text of the Act did not include the recoupment provision. The second strike to the safeguards came with President Reagan's memorandum of 1983 that eased the restrictions for large companies to benefit from Bayh-Dole (see Woolley and Peters 2009a, for Memorandum on Government Patent Policy of February 18, 1983). Congress later amended the Act according to this memorandum, further striking down the five-year limitation on exclusive licensing for large companies in Trademark Clarification Act of 1984 (PL 98-620). Furthermore, the provision for agency intervention was by design impractical given that its application requires meeting the high threshold of "exceptional circumstances." In fact, the sole place where this provision has been used is a solicitation for molecular target laboratories by the National Cancer Institute (2000).

Likewise, regarding the march-in rights provision, Admiral Hyman Rickover, famous for directing the development of the nuclear submarine, warned during the hearings that it was impractical for the government to supervise the development of technology sufficiently to justify the use of march-in rights. The admiral thought of it as simply a cosmetic provision crafted to placate objectors to the Act. In time, his fears proved warranted. As this provision was regulated (37 CFR 401.6), agencies considered exercising the rights only upon petition of a disaffected third party, and under the Trademark Clarification Act of 1984, any march-in determination is held in abeyance until the appeal process is exhausted (P.L. 98-620; §V-9). It is thus not surprising that only three petitions have been presented, and all were found unjustified by the National Institutes of Health (NIH) (see details in the next section).

Asserting that the changes to the terms of the Bayh-Dole debate and the changes to its design reflect the ascendancy of neoliberal ideas in US policy making, is not sufficient to evaluate these changes. If we think that the value of the technology transfer regime resides in its ability to streamline commercialization of public research, the current terms of the debate would not be a concern at all. If instead we see technology transfer policy as serving various public values other than those related to commercialization, we should assess how well the Act is performing with respect to those values. To this end, the next section will introduce the evaluation approach called "public value failure" and deploy it on Bayh-Dole.

\section{Public Value Failure in the Bayh-Dole Regime}

The most influential rationale for policy evaluation is known as Market Failure Criteria. This is a normative theory for public action that justifies government intervention in the economy when markets fail to behave as perfectly competitive markets (Bator 1958; Samuelson 1954). The notion of perfect competition is an ideal state of frictionless markets where consumers and producers transact with complete 
and perfect information such that prices convey all the relevant information about the goods transacted. The fundamental assumption of market failure is that perfectly competitive markets allocate resources efficiently in a Pareto optimal sense, that is, no person can be made better off without making another worse off.

This specific definition of efficiency, that means all markets clear at current prices, is silent about the pattern of distribution of resources. This point can be sufficiently illustrated by a stylized economy of two individuals who must divide a loaf of bread. An efficient allocation, in the Pareto optimal sense, is any allocation that exhausts the loaf; for instance, each person gets half, or one person gets the entire loaf while the other gets nothing. Perfect competition guarantees an efficient allocation in this specific sense (no bread is wasted), but it should be noted, too, that perfect competition supports any allocation of resources, however intolerable or unjust such an allocation is.

Notwithstanding this inadequacy dealing with issues of distribution, market failure became enormously influential in policy analysis and policy-making circles in the U.S. partly because it was vested with all the scientific authority that economic theory could muster-general equilibrium theory-and partly because it provided the Cold War generation with a rationale for government intervention that did not betray their commitment to the market system, quite the contrary: it celebrated markets. Such is the sway of market failure, that its method par excellence, cost-benefit analysis, was instituted as the norm when assessing prospectively federal regulatory initiatives-following President Reagan's E.O. 12291 of 1981 and President Clinton's E.O. 12866 of $1994 .^{8}$

In spite of its popularity, market failure has a fundamental problem because social groups do not always value efficiency or the freedom of market as a superordinate goal. Rather, societies often balance the free markets against other values like security or justice, and as a consequence, governments may be fully justified to take action even when markets do not fail. Consider the case of basic necessities such as housing, food, or medicine. At any price level_even at the marginal cost of production, that is, the price of perfect competition-there will be a segment of the population unable to afford those prices. If social values were such that the provision of basic necessities to all citizens overrides the value of free markets; then, the government would have reasons to secure the provision of those goods for the entire population.

To escape this fundamental narrowness of market failure, Bozeman (2002) proposed an alternative rationale, called Public Value Failure Criteria, that expands the analysis to non-market values. Whereas market failure prescribes public action only to restore perfect competition, public value failure prescribes action when any of several discrete "core public values" go underserved or neglected. This begs the question of which public values exactly? In answering this question Bozeman produced a canonical set of public values that reflects well-established convictions about the rule of law and democratic policy-making (e.g. transparency, inclusiveness) but that are also distilled from a pragmatic theory of the public interest in

\footnotetext{
${ }^{8}$ It should be noted that President Reagan's executive order introduced cost-benefit analysis as part of the Regulatory Impact Analysis. The RIA also mandates the assessment of distributive and fairness impacts, although these are not formalized in a method in the same way as cost-benefit analysis.
} 
democracy in the tradition of Dewey's The Public and Its Problems (Dewey 1927; the theory in Bozeman 2007: Chap. 5). This canonical set of public values is referred to as "public value failure criteria" (Bozeman 2002) or as "public value mapping criteria" (PVM-C) when embedded in the public value mapping method (see Bozeman and Sarewitz, this issue).

Note that assessing policy with the public value failure criteria is a "negative test," in the sense that it helps to identify failures to serve the public interest rather than to positively affirm whether a given policy is in fact furthering the common good. Bozeman formulated his criteria - the core set of public values-in such a way that it symmetrically counterposes the market failure criteria. Taking this symmetry in consideration, I have adapted Bozeman's criteria for the particular purpose of evaluating Bayh-Dole.

Table 1 summarizes Bozeman's public value failure criteria (first column), transposes it to the Bayh-Dole problem (second column), and summarizes the main public value failures (third column) that are described in detail next.

\section{Equal Voice and Equal Consideration}

A failure of aggregation of interests, occurs, explains Bozeman (2002), when "core public values are skirted because of flaws in the policy-making processes" (p. 151). These failures could be attributed to ill-designed institutions governing the policy process, or the failures could be procedural when they are due to a willful or heedless deviation from due process. Procedural flaws could be uncovered by process audits and are commonly attributed to negligence or corruption. Failures of

Table 1 Summary assessment of Bayh-Dole with PVM criteria

\begin{tabular}{lll}
\hline $\begin{array}{l}\text { Public value failure criteria. In } \\
\text { parenthesis, the market failure } \\
\text { analog. }\end{array}$ & $\begin{array}{c}\text { Equivalent criteria } \\
\text { for evaluation of } \\
\text { Bayh-Dole. }\end{array}$ & Brief description of the failure. \\
\hline $\begin{array}{l}\text { Interest aggregation and } \\
\text { articulation (general failures of } \\
\text { the price system). }\end{array}$ & $\begin{array}{c}\text { Equal voice and equal } \\
\text { consideration. }\end{array}$ & $\begin{array}{c}\text { Opposition to Bayh-Dole was neutralized by } \\
\text { ill-designed safeguards that were easily } \\
\text { defused and struck down. }\end{array}$ \\
$\begin{array}{c}\text { Legitimate monopolies } \\
\text { (monopolies and non- } \\
\text { competitive market structures). }\end{array}$ & $\begin{array}{c}\text { Legal attributions of } \\
\text { government. }\end{array}$ & $\begin{array}{c}\text { Failure to enforce march-in rights for } \\
\text { controlling excesses of monopolistic } \\
\text { pricing. }\end{array}$ \\
$\begin{array}{c}\text { Imperfect public information } \\
\text { (asymmetric information). }\end{array}$ & $\begin{array}{c}\text { Transparency. } \\
\text { Failure to support universities balancing } \\
\text { organizational needs and the public interest. }\end{array}$ & $\begin{array}{c}\text { No formal channels for holding } \\
\text { implementation agents (OTTs) } \\
\text { accountable. }\end{array}$ \\
$\begin{array}{c}\text { Distribution of benefits (benefit } \\
\text { hoarding and rent-seeking). }\end{array}$ & $\begin{array}{c}\text { Preclusion of benefit } \\
\text { hoarding. }\end{array}$ & $\begin{array}{c}\text { Lack of institutional mechanisms to } \\
\text { determine "imperatives" for exclusive } \\
\text { licensing. }\end{array}$ \\
$\begin{array}{c}\text { Provider availability } \\
\text { (monopsonies and non- } \\
\text { competitive chains of supply). }\end{array}$ & $\begin{array}{c}\text { Provision of public } \\
\text { goods and services. }\end{array}$ & $\begin{array}{c}\text { Exclusion of firms willing to develop } \\
\text { applications in a competitive environment. }\end{array}$ \\
\hline
\end{tabular}


design are harder to detect because the system may work by-the-book. Bozeman (2002, 2007) offers an example of structural problems facilitated by the seemingly reasonable rule of seniority for the chairmanship of Congressional committees; the problem was that this rule enabled tenured Southern congressmen to impede Civil Rights reforms for decades until the mid 1960s. Likewise, analyzing U.S. science policy, Bozeman and Sarewitz (2005) characterize another structural flaw, arguing that the science policy system of the U.S. does not have a mechanism to involve lay citizens in crucial policy decisions such as the portfolio allocation of federal research funds. In both cases, policy-making institutions work according to design and still widely held public values (such as equal rights or social returns on public investments) fail to be articulated and the resulting policy aggregates the competing values unduly privileging some stakeholders over others.

The swift passage of Bayh-Dole suggests bipartisan cooperation, a success of aggregation of interests. Nevertheless, it should be remembered that the sponsors of the Act had anticipated opposition and crafted provisions to address each major objection. This tactic effectively neutralized opposition.

The degree to which the policy drifted from the seeming compromise of its first statutory version may not have been suspected by the sponsors of the bill, and surely, it was not foreseen by the opposition that was placated with the safeguard provisions. In retrospect, one is left wondering if the safeguards were mainly introduced to deflect objections rather than give objections due consideration. Were the voices of dissent given due consideration or were they simply assuaged under the pretense of safeguard provisions and the urgency of implementing solutions to the competitiveness crisis? The hearings of Bayh-Dole cannot be charged for failing to give equal voice to proponents and objectors; it is doubtful, however, that all voices have been given equal consideration consistently since 1980 when the Act was enacted.

\section{Legal Attributions of Government}

A public value failure occurs when private individuals or institutions exercise rights that are the exclusive privilege of government, such as speaking on behalf of the whole of society or making law and regulations to protect the public interest. For instance, foreign policy and the prevention of a flu pandemic, argue Bozeman (2002) and Feeney and Bozeman (2007) respectively, are both responsibilities and attributions of the government that no individual or organization can take upon itself to provide. Likewise, Bozeman and Sarewitz (2005) warn of public value failure when little or no governmental authority is executed to protect the physical and mental integrity of human subjects participating in clinical trials. When researchers conducting those studies have an economic interest in the companies producing the drugs tried, a public value failure ensues if the researcher's conflict of interest is not fully disclosed to participants because it cannot be assumed that subjects who consented to participate were fully informed of the benefits and risks of their participation.

Likewise, the enforcement of march-in rights in the face of excessive pricing and other monopolistic practices is a statutory attribution of government, and the failure to enforce has been indeed a public value failure. Three cases were brought to a 
federal agency petitioning the use of march-in rights - the three were dismissed. In the first case, CellPro, Inc. had intended to license patents granted to competitor Baxter by Johns Hopkins University (developed with NIH grants). NIH found that Baxter was actively practicing the patent seeking FDA approval on a device with those patents; provided that Bayh-Dole requires only reasonable effort to practice the patent, the NIH rejected the petition (NIH 1997). The other two cases regarding drugs Norvir, an HIV/AIDS treatment, and Xalatan, a treatment for glaucoma, merited a similar conclusion from the NIH (see resolutions in NIH 2004a, b). In both cases, the petitioners had complained of excessive pricing and requested the government to exercise its royalty-free license with respect to titles held by Abbott Laboratories and Pfizer respectively. However, NIH stressed that, under Bayh-Dole, the exercise of march-in rights was limited to circumstances where the patents in question were not practiced or to alleviate health and safety needs, neither of which applied to Norvir and Xalatan that were already commercial products. The NIH concluded that "the extraordinary remedy of march-in is not an appropriate means of controlling prices" (NIH 2004b). This interpretation is nevertheless controversial; for instance, legal scholars Arno and Davis (2001, p. 662) find "countless references in the legislative record to the need to maintain competitive market conditions through the exercise of march-in rights," including the control of profits and prices.

The neglect to affirm march-in rights is as much a public value failure in patent policy as it would be laxity in enforcing informed consent in the regulation of human subject in research. The weakening of the safeguards built-in the Act partly explains the observed government tolerance of monopolistic practices, but it does not justify the three-decade neglect of regulatory support to universities in dealing with the tensions of revenue-seeking licensing activities and their public service mission. It is worthwhile to stress that government-backed institutions would greatly assist universities in their efforts for good governance and self-regulation.

\section{Transparency}

The citizens' ability to exercise oversight over the policy process, from design to implementation, is often considered a public value of consensus. Bozeman (2007) argues that lack of transparency in the policy process inhibits this ability resulting in a public value failure. The canonical examples are closed-door executive meetings such as the Clinton task force for health care reform (Hacker 1997) or the Cheney talks on energy policy (Bozeman 2007); neither the First Lady nor the Vice President transgressed due process but they both met deep skepticism from various publics who, with good reason, interpreted the lack of transparency as a threat to the public interest.

In contrast to these examples of public value failure, the passing of Bayh-Dole, while swift, was indeed subject to customary hearings and debate. It may not be easy to challenge the fact that the Act was enacted in a public and transparent fashion. Its implementation, on the other hand, is not so obviously transparent. Admittedly, the implementation of the core logic of the Act is straightforward: the government confers rights of intellectual ownership to research contractors (e.g. 
universities, hospitals, etc.) and demands minimal reporting requirements from them. Nevertheless, the implementation of the Act's safeguards of the public interests is much less transparent. Granting of rights to research contractors should also be construed as a delegation of the government's fiduciary duty to society with respect to publicly funded innovation. At the same time, university offices of technology transfer are constituted with the clear mission to profitably commercialize university inventions. Seeking to find a market for those inventions is as much a business as real estate or venture capital. Whether the OTT is constituted inside the organization (as a division or department) or outside (as an independent legal vehicle), its performance will primarily be assessed by revenue generation. Revenue is derived from licensing patents in two modalities, cash or stock options in the licensee firms. Hence, many of the companies licensing from the university will be start-ups founded by faculty members working on a particular invention and will partner with the OTT that provides them with the resources and legal expertise to develop their high-technology products. In this partnership the OTT is constituted across two spheres, the university and the industry. It is crucial for the firm to keep private information secret if the firm is to successfully position itself in the marketplace-information that includes technical aspects of the product under development, the configuration of the supply chain, and the marketing and business strategy of the firm. The OTT is the most important partner for the firm at this early stage and must be committed to secrecy if it is to be a valuable partner; consequently, the OTT cannot be expected to function adequately if it is open to public scrutiny. This is a public value failure by design: the burden of implementation of Bayh-Dole befalls on organizations that straddle the public and the private and therefore cannot be entirely transparent. In fact, the OTT by design sits astride the public spheres of knowledge creation and the private spheres of profit making and is therefore ill equipped to internalize the ensuing tensions because the delegation of Bayh-Dole is much more clear about implementing the profit incentive than it is delegating the government's fiduciary duty.

\section{Preclusion of Benefit Hoarding}

The best example of this public value failure concerns precisely technology transfer policy. Bozeman and Sarewitz (2005) explain how the Federal Technology Transfer Act of 1986 (15 U.S.C. \$3701-3714), that instituted cooperative agreements (CRADAs) between federal laboratories and industry, resulted in one visible case in the commercialization of a technology design to hoard the benefits of improved varieties of seeds. Seed-sterilizing technology, also called the terminator-gene, was developed under a CRADA between the Department of Agriculture and Delta and Pine Land Co., as a complex bioengineered procedure that prevents farmers from producing second-generation seeds from first-generation crops, thus enforcing intellectual property rights on new varieties of seed. Small farmers, including subsistence farmers in the developing world, explained these authors, "continually seek better plant varieties for local growing conditions, through careful selection of kept seed, as well as purchase of new varieties from both public and private seed 
distributors" (Bozeman and Sarewitz 2005, p. 131). Seed-sterilizing technology prevents such practices and deprives vulnerable farmers from free riding the new seed varieties. However, the purpose of government for funding research to improve agricultural methods including the engineering of seeds for better crop varieties is to improve stability and sufficiency of the food supply by means of improving the productivity of arable land, irrigation, and crops. Seed-sterilizing technology does not serve that purpose or the values that inspire it.

It would be a mistake to blame the CRADAs mechanism for the development of seed-sterilizing technology. Rather, the cause for this public value failure is the lack of institutional safeguards of the public interest that upon discovery of the terminator-gene did not prevent a firm from obtaining rights to the patents of such a technology. This lesson resonates with the implementation of Bayh-Dole because the problem in this case is not the profit incentive but the assumption that monopolistic profits are the only level of incentive that will bring about the development and commercialization of research. Exclusive licensing is hardly warranted when fundamental discoveries or research tools are in question or when the application is nearly contained in the patent. In the former, the collective efforts of a research community could be throttled; in the latter, a competitive environment would better serve the wide dissemination of the technology. Thus, unless there is only one company willing to develop an application with a public-research patent, exclusive licensing of such a patent is a form of benefit hoarding.

\section{Provision of Public Goods and Services}

Even when private initiative is motivated by public values, as is the case of charity, the entrepreneur may decide the time, quality, and form of the service, and may even decide to discontinue its provision, at his discretion. When the government provides a service motivated by public values, any changes in the service level and quality should a priori reflect a change of values or a shift in the way public values organize public priorities. However, when the government delegates to a contractor the provision of a given service, private discretion over the provision may not represent a change in public values as much as it will be a change in the determinants of the bottom-line of the contractor. Bozeman (2007) declares that a public value failure will occur in a situation where the government, having delegated a given service in the past, finds itself in a situation where the need emerges to provide that service with urgency, yet neither it can avail itself of contractors nor it has the capacity to provide the needed service anymore.

As was discussed earlier, Bayh-Dole solved a two-sided problem by simultaneously providing an incentive for demand and supply of R\&D by motivating a greater concern for mission-oriented research and by granting legal protection to developmental investors respectively. In this sense, Bayh-Dole provides two public goods of great value: more socially sensitive research and lesser risk for technology developers. Was there a shortage of these services before the Act? Research is not conclusive on this respect but one thing is certain: the abrupt increase of transferring activity since 1980 must have reduced any shortage or even perhaps turned it into a 
surplus. Yet, not every exclusive license granted is justified. To the extent that research tools are licensed exclusively, Bayh-Dole is reducing the availability of technological applications that would exist if those tools would be licensed on a non-exclusive basis (Mazzeloni and Nelson 1998; Colyvas et al. 2002). Likewise, the cases where there is at least one company willing to take a non-exclusive license and develop a technology in a competitive environment (typical of some industries such as software and mobile telephony), an exclusive license is actually curtailing other firms from providing new products at competitive prices. In the absence of institutional mechanisms that restrain monopolistic excesses, the Act has two edges, one that expands the demand and supply of economically valuable R\&D and another that cuts the number of potential providers. Again, appropriate institutional mechanisms could keep the incentives of the Act in place and, at the same time, maximize the number of research programs and developers willing to compete with each other in a race that promotes the public interest.

\section{Conclusion}

The direction of the Bayh-Dole debate was influenced by the new political and economic context in which it unfolded. Neoliberal conceptions of the economy, innovation, and property rights came to dominate the political discourse since the 1980s and the Bayh-Dole debate became dominated by the banners of the imperative of innovation and especially "competitiveness." This situation and the attrition of countervailing forces in the enacting coalition allowed for a legislative drift of the Act and a rollback of safeguards introduced to protect economic opportunity and access, increasing in this way the authority of markets.

In terms of public value failures, it could be said that with the passing of time, voice and consideration is less and less equal in the Bayh-Dole debate, that the legitimate attributions of government are in retreat, and that the ambiguity of the delegation of the fiduciary role is condoning an environment of business secrecy. The enthusiasm for a hands-off government has resulted in a vacuum of institutional safeguards of economic opportunity; a vacuum manifested in the NIH inability to exercise march-in rights due to its narrow interpretation of that provision, and manifested, too, in the lack of government support for universities that were left to their own resources to countervail the force of financial need with the more tenuous commitment to public service.

Open Access This article is distributed under the terms of the Creative Commons Attribution Noncommercial License which permits any noncommercial use, distribution, and reproduction in any medium, provided the original author(s) and source are credited.

\section{References}

Arno, Peter S., and Michael H. Davis. 2001. Why don't we enforce existing drug price controls?: The unrecognized and unenforced reasonable pricing requirements imposed upon patents deriving in whole or in part from federally funded research. Tulane Law Review 75: 632-693. 
Baumol, William J., Richard R. Nelson, and Edward N. Wolff. 1994. Convergence of productivity: Crossnational studies and historical evidence. New York: Oxford University Press.

Bayh, Birch, Joseph Allen, and Howard W. Bremer. 2009. Universities, inventors and the Bayh-Dole Act. Life Sciences Law and Industry Report 24(3): 1-5.

Bator, Francis M. 1958. The anatomy of market failure. The Quarterly Journal of Economics 72(3): 351-379.

Bozeman, Barry. 2002. Public value failure: When efficient markets may not do. Public Administration Review 62(2): 134-151.

Bozeman, Barry. 2007. Public Values and the Public Interest. Washington: Georgetown University Press.

Bozeman, Barry, and Daniel Sarewitz. 2005. Public values and public failure in U.S. science policy. Science and Public Policy 32(2): 119-136.

Bruno, Isabelle. 2009. The "indefinite discipline" of competitiveness benchmarking as a neoliberal technology of government. Minerva 47(3): 261-280.

Cohen, Wesley M., Richard R. Nelson, and John P. Walsh. 2000. Protecting their intellectual assets: Appropriability conditions and why U.S. manufacturing firms patent (or not). NBER working papers, no. 7552. Cambridge: National Bureau of Economic Research.

Cohen, Wesley M., Richard R. Nelson, and John P. Walsh. 2002. Links and impacts: The influence of public research on industrial R\&D. Management Science 48(1): 1-23.

Colyvas, Jeannette, Michael Crow, Annetine Gelijns, Roberto Mazzoleni, Richard R. Nelson, Nathan Rosenberg, and Bhaven N. Sampat. 2002. How do university inventions get into practice? Management Science 48(1): 61-72.

Dewey, John. 1927. The public and its problems. New York: Henry Holt.

Eisenberg, Rebecca S. 1996. Public research and private development: patents and technology transfer in government- sponsored research. Virginia Law Review 82(8): 1663-1727.

Gibbons, Michael, Camille Limoges, Simon Schwartzman, Helga Nowotny, Martin Trow, and Peter Scott. 1994. The new production of knowledge: The dynamics of science and research in contemporary societies. Thousand Oaks: Sage.

Greenberg, Daniel S. 2007. Science for sale: The perils, rewards and delusions of campus capitalism. Chicago: University of Chicago Press.

Fagerberg, Jan. 1988. International competitiveness. Economic Journal 98(391): 355-374.

Feeney, Mary K., and Barry Bozeman. 2007. Public values and public failure: Implications of the 2004-2005 flu vaccine case. Public Integrity 9(2): 175-190.

Guston, David H. 2000. Between politics and science: Assuring the integrity and productivity of research. Cambridge: Cambridge University Press.

Hacker, Jacob S. 1997. The road to nowhere: The genesis of President Clinton's plan for health security. Princeton: Princeton University Press.

Harvard Business Review. 2010. The HBR list: Breakthrough ideas for 2010. Harvard Business Review (Jan-Feb).

Harvey, David. 2007. A brief history of neoliberalism. Oxford: Oxford University Press.

Haskins, Keshia B. 1998. Special 301 in China and Mexico: A policy which fails to consider how politics, economics, and culture affect legal change under Civil Law systems of developing countries. Fordham Intellectual Property, Media and Entertainment Law Journal 9: 1125-1170.

Hatsopoulos, George N., Paul R. Krugman, and Lawrence H. Summers. 1988. US competitiveness: Beyond the trade deficit. Science 241(4863): 299-307.

Heller, Michael A. 1998. The tragedy of the anticommons: Property in the transition from Marx to markets. Harvard Law Review 111(3): 621-688.

Heller, Michael A., and Rebecca S. Eisenberg. 1998. Can patents deter innovation? The anticommons in biomedical research. Science 280(5364): 698-701.

Henderson, Rebecca, Adam B. Jaffe, and Manuel Trajtenberg. 1998. Universities as a source of commercial technology: A detailed analysis of university patenting 1965-1988. The Review of Economic Statistics 80: 119-127.

Hood, Christopher. 1991. A public management for all seasons? Public Administration 69: 3-119.

Hood, Christopher, and Guy Peters. 2004. The middle aging of new public management: Into the age of paradox. Journal of Public Administration Research and Theory 14(3): 267-282.

Horn, Murray J., and Kenneth A. Shepsle. 1989. Commentary on "Administrative arrangements and the political control of agencies": Administrative process and organizational form as legislative responses to agency costs. Virginia Law Review 75(2): 499-508. 
Jaffe, Adam, and Josh Lerner. 2004. Innovation and its discontents: How our broken patent system is endangering innovation and progress and what to do about it. Princeton: Princeton University Press.

Jensen, Richard, and Marie Thursby. 2001. Proofs and prototypes for sale: The licensing of university inventions. The American Economic Review 91(1): 240-259.

Judson, Horace F. 2004. The great betrayal: Fraud in science. Orlando: Harcourt.

Kenney, Martin, and Donald Patton. 2009. Reconsidering the Bayh-Dole Act and the current university invention ownership model. Research Policy 38: 1407-1422.

Klein, Lawrence R. 1988. Components of competitiveness. Science 241(4863): 308-313.

Krugman, Paul. 1994. Competitiveness: A dangerous obsession. Foreign Affairs 72(2): 28-44.

Levin, Richard C., Alvin K. Kevorick, Richard R. Nelson, and Sidney G. Winter. 1987. Appropriating the returns from industrial research and development. Brookings Papers on Economic Activity 3: $783-820$.

Litan, Robert E., Lesa Mitchell, and E. J. Reedy. 2007. The university as innovator: Bumps in the road. Issues in Science and Technology. http://www.issues.org/23.4/litan.html. Accessed 15 May 2009.

Lowi, Theodore J. 1995. The end of the Republican era. Norman: University of Oklahoma Press.

Mazzeloni, Roberto, and Richard R. Nelson. 1998. The benefits and costs of strong patent protection: A contribution to the current debate. Research Policy 27(3): 273-284.

McCloskey, Herbert, and John Zaller. 1984. The American ethos: Public attitudes toward capitalism and democracy. Cambridge: Harvard University Press.

Meeropol, M. 1998. Surrender: How the Clinton administration completed the Reagan revolution. Ann Arbor: University of Michigan Press.

Merges, Robert P., and Richard R. Nelson. 1990. On the complex economics of patent scope. Columbia Law Review 90: 839-916.

McCubbins, Matthew D., Roger G. Noll, and Barry R. Weingast. 1987. Administrative procedures as instruments of political control. Journal of Law Economics and Organization 3(2): 243-277.

Mirowski, Philip, and Esther-Mirjam Sent. 2007. The commercialization of science and the response of STS. In The Handbook of Science and Technology Studies, 3rd ed, eds. Edward J. Hackett, Olga Amsterdamska, Michael Lynch, and Judy Wajcman, 635-690. Cambridge: The MIT Press.

Mirowski, Philip. 2009. Postface: Defining neoliberalism. In The road from Mont Pèlerin: The making of the neoliberal thought collective, eds. Philip Mirowski, and Dieter Plehwe, 417-455. Cambridge: Harvard University Press.

Mowery, David C., Richard R. Nelson, Bhaven N. Sampat, and Arvids A. Ziedonis. 2004. Ivory tower and industrial innovation: University-industry technology before and after the Bayh-Dole Act in the United States. Stanford: Stanford University Press.

Mowery, David C., and Arvids A. Ziedonis. 2002. Academic patent quality and quantity before and after the Bayh-Dole Act in the United States. Research Policy 31: 399-418.

National Cancer Institute. 2000. Solicitation, molecular target laboratories. Commerce Business Daily, published in CBDNet on February 18, 2000.

National Institutes of Health. 1997. Determination in the case of petition of Cellpro, Inc. August. http://www.nih.gov/news/pr/aug97/nihb-01.htm. Accessed 12 June 2009.

National Institutes of Health. 2004a. Determination in the case of Norvir manufactured by Abbott Laboratories, Inc. July 2. http://ott.od.nih.gov/policy/March-In-Norvir.pdf. Accessed 12 June 2009.

National Institutes of Health. 2004b. Determination in the case of Xalatan manufactured by Pfizer, Inc. September 1. http://ott.od.nih.gov/policy/March-in-Xalatan.pdf. Accessed 12 June 2009.

National Research Council. 2010. Managing University intellectual property in the public interest. Washington, D.C.: The National Academies Press.

Nedeva, Maria, and Rebecca Boden. 2006. Changing science: The advent of neo-liberalism. Prometheus 24(3): 269-281.

Nowotny, Helga, Peter Scott, and Michael Gibbons. 2001. Re-thinking science: Knowledge and the public in an age of uncertainty. Malden: Blackwell.

Nowotny, Helga, Peter Scott, and Michael Gibbons. 2003. Introduction. 'Mode 2' revisited: The new production of knowledge. Minerva 41(3): 179-194.

Pestre, Dominique. 2003. Regimes of knowledge production in society: Towards a more political and social reading. Minerva 41(3): 245-261.

Pestre, Dominique. 2005. The technosciences between markets, social worries and the political: How to imagine a better future? In The public nature of science under assault: Politics, markets, science, and the law, eds. Helga Nowotny, Dominique Pestre, Eberhard Schmidt-Aßmann, Helmuth SchulzeFielitz, and Hans-Heinrich Trute, 29-52. New York: Springer. 
Plehwe, Dieter, and Bernhard Walber. 2006. Between network and complex organization: The making of neoliberal knowledge and hegemony. In Neoliberal hegemony: A global critique, eds. Bernhard Walpen, Dieter Plehwe, and Gisela Nuenhöffer, 27-70. London: Routledge.

Pollin, Robert. 2003. Contours of descent: U.S. economic fractures and the landscape of global austerity. London: Verso.

Pollit, Christopher, and Geert Bouckaert. 2004. Public management reform: A comparative analysis, 2nd ed. New York: Oxford University Press.

Porter, Michael E. 1980. Competitive strategy: Techniques for analyzing industries and competitors. New York: The Free Press.

Porter, Michael E. 1990. The competitive advantage of nations. New York: The Free Press.

Rafferty, Matthew. 2008. The Bayh-Dole Act and university research and development. Research Policy 37: 29-40.

Sampat, Bhaven N. 2006. Universities and intellectual property: Shaping a new patent policy for government funded academic research. In Shaping science and technology policy: The next generation of research, eds. David H. Guston, and Daniel Sarewitz, 55-76. Madison: The University of Wisconsin Press.

Sampat, Bhaven N., David C. Mowery, and Arvids A. Ziedonis. 2003. Changes in university patent quality after the Bayh-Dole Act: A re-examination. International Journal of Industrial Organization 21(9): 1371-1390.

Samuelson, Paul A. 1954. The pure theory of public expenditure. The Review of Economics and Statistics 36(4): 387-389.

Scherer, F. Michael. 2009. The political economy of patent policy reform in the United States. Journal of Telecommunications and High-Technology Law 7(2): 101-148.

Schneider, Anne L., and Helen Ingram. 1997. Policy design for democracy. Lawrence: University of Kansas Press.

Shapiro, Carl. 2000. Navigating the patent thicket: Cross licenses, patent pools, and standard setting. Innovation Policy and the Economy 1: 119-150.

Slaughter, Sheila, and Larry L. Leslie. 1997. Academic capitalism: Politics, policies, and the entrepreneurial university. Baltimore: Johns Hopkins University Press.

Slaughter, Sheila, and Gary Rhoades. 1996. The emergence of a competitiveness research and development policy coalition and the commercialization of academic science and technology. Science, Technology, and Human Values 21(3): 303-339.

Slaughter, Sheila, and Gary Rhoades. 2004. Academic capitalism and the new economy: Markets, state, and higher education. Baltimore: Johns Hopkins University Press.

Stevens, Ashley J. 2004. The Enactment of Bayh-Dole. Journal of Technology Transfer 29(1): 93-99.

Turner, Rachel S. 2008. Neo-liberal ideology: History, concepts and policies. Edinburgh: Edinburgh University Press.

Thursby, Jerry, and Marie Thursby. 2006. Where is the new science in corporate R\&D. Science 314(8): $1547-1548$.

U.S. Senate. 1980. Statement of Senator Birch Bayh to the Committee on the Judiciary and Commerce, on government patent policy, January 25, 1980. Washington, D.C.: Government Printing Office.

Van Horn, R., and Philip Mirowski. 2009. The rise of the Chicago school of economics and the birth of neoliberalism. In The road from Mont Pellerin: The making of the neoliberal thought collective, eds. Philip Mirowski, and Dieter Plehwe, 139-178. Cambridge: Harvard University Press.

Walsh, John P., Ashish Arora, and Wesley M. Cohen. 2003. The patenting and licensing of research tools and biomedical innovation. In Patents in the knowledge-based economy, eds. Wesley M. Cohen, and Stephen A. Merrill, 285-340. Washington, D.C.: The National Academies Press.

Washburn, Jennifer. 2005. University Inc.: The corporate corruption of higher education. New York: Basic Books.

Woolley, John T., and Gerhard Peters. 2009a. The American Presidency Project [online]. University of California Santa Barbara. http://www.presidency.ucsb.edu/ws/?pid=3130. Accessed 8 Jan 2009.

Woolley, John T., and Gerhard Peters. 2009b. The American Presidency Project [online]. University of California Santa Barbara. http://www.presidency.ucsb.edu/ws/?pid=40945. Accessed 8 Jan 2009.

Zaller, J.R. 1992. The nature and origins of mass opinion. New York: Cambridge University Press. 